\title{
Biotinylation of Bacillus thuringiensis Insecticidal Crystal Proteins
}

\author{
P. DENOLF, ${ }^{1,2 *}$ S. JANSENS, ${ }^{1}$ S. VAN HOUDT, ${ }^{1,2}$ M. PEFEROEN, ${ }^{1}$ D. DEGHEELE, ${ }^{2}$ AND J. VAN RIE ${ }^{1}$ \\ Plant Genetic Systems, J. Plateaustraat $22,{ }^{1}$ and Laboratorium voor Agrozoölogie, ${ }^{2}$ B-9000 Ghent, Belgium
}

Received 4 December 1992/Accepted 1 April 1993

\begin{abstract}
Biotinylation of Bacillus thuringiensis insecticidal crystal proteins (ICPs) was evaluated for its potential use in an alternative ICP screening method and in the characterization of ICP receptors. In vivo biological activity of CryIA(b), as inferred from bioassays with Manduca sexta and Ostrinia nubilalis and from histopathological effects on $O$. nubilalis midgut cells induced by force feeding, was not affected by biotinylation at moderate biotinylation ratios. A competitive radioreceptor assay showed that there was only a minor reduction in binding affinity of biotin-labeled CryIA(b) for $M$. sexta brush border membrane vesicles. On midgut tissue sections, the binding pattern along the midgut epithelium and the staining intensity of biotinylated ICPs detected with streptavidin-enzyme conjugate were virtually identical to the binding pattern and staining intensity of native CryIA(b) detected with antibodies. The specificity of biotinylated ICP binding to larval midgut tissue was demonstrated by performing homologous competition experiments. The relationship between different ICP receptor types in Plutella xylostella, as inferred from radioligand binding studies, was confirmed by the results of heterologous competition experiments performed with biotinylated and native ICPs.
\end{abstract}

During sporulation Bacillus thuringiensis produces parasporal, proteinaceous inclusions. After ingestion by sensitive insect larvae the inclusions are solubilized in the larval midgut. Solubilized proteins (insecticidal crystal proteins [ICPs] or delta-endotoxins) are activated by midgut proteases, which convert the ICPs into smaller toxic proteins. Binding of the toxins to midgut epithelial cell surface receptors induces pore formation $(23,33)$, disturbing the osmotic balance of the midgut epithelial cells. As a result of cell lysis, gut paralysis, and consequent starvation, the insect larvae die $(8,30)$.

The majority of $B$. thuringiensis strains identified produce ICPs that exhibit highly specific activity against lepidopteran (caterpillar), dipteran (mosquito and blackfly), or coleopteran (beetle) larvae $(10,24,27)$. The specificity of the various ICPs is primarily determined by the presence of different types of high-affinity binding sites in the midgut epithelium of susceptible larvae $(18,35,36)$. Depending on the distinct receptors present, one or more ICP types can bind. The importance of specific ICP receptors is further demonstrated by the modification of ICP-receptor interactions in insect larvae that have developed resistance to ICPs $(11,37)$.

B. thuringiensis ICPs offer an attractive alternative to the use of synthetic insecticides for insect pest management. In view of the increasing concern about human health and environmental safety, it is expected that the use of these ICPs in insect control will increase. As a consequence, selection pressure on target insects will probably increase. If single toxins are applied on a large scale, this could lead to more rapid development of insect resistance.

In order to forestall the onset of resistance in natural insect populations, workers must focus on the design of resistance management strategies. One possibility is to apply mixtures or rotations of ICPs that interact with different receptor sites $(14,16,29)$. Until now, the identification of interesting ICPs and the characterization of the ICP recep-

* Corresponding author. tors in an insect species have been laborious, requiring the rearing of masses of insect larvae for toxicity assays and radioligand binding experiments $(18,35)$. Immunohistochemical binding analyses of midgut tissue sections have eliminated the need for large numbers of insect larvae to be dissected and have allowed binding studies to be done with single insects (5). However, this technique requires antibodies for the detection of the ICPs and does not give any information about the relationships between the different ICP receptors present in an insect species. As an alternative, we investigated the use of biotinylated ICPs and tissue sections to screen for $B$. thuringiensis ICPs with a novel insecticidal spectrum and to permit the characterization of ICP receptors.

\section{MATERIALS AND METHODS}

Purification and activation of $B$. thuringiensis ICPs. The CryIA(a), CryIA(b), CryIB, CryID, and CryIE ICPs were obtained as recombinant proteins expressed in Escherichia coli. The $\operatorname{cry} L A(b)$ gene was cloned from $B$. thuringiensis subsp. berliner 1715 (19). The gene for CryIB was cloned from $B$. thuringiensis subsp. entomocidus HD-110; its sequence is identical to the sequence described by Brizzard and Whiteley (6). The $c r y L A(a)$ and $c r y I D$ genes were cloned from $B$. thuringiensis subsp. aizawai $\operatorname{HD68}(20,21)$, and the cryIE gene was cloned from $B$. thuringiensis subsp. darmstadiensis HD146 (38).

B. thuringiensis subsp. kurstaki HD73 produces crystals containing only one ICP, CryIA(c) (25). A culture of this strain was grown as described by Mahillon and Delcour (28). The autolyzed culture was centrifuged for $20 \mathrm{~min}$ at $1,200 \times$ $g$ and washed with a buffer containing $20 \mathrm{mM}$ Tris, $100 \mathrm{mM}$ $\mathrm{NaCl}$, and $0.05 \%$ Triton $\mathrm{X}-100(\mathrm{pH} \mathrm{8})$. The final pellet was resuspended in this buffer $(4 \mathrm{ml}$ buffer for a $100-\mathrm{ml}$ culture), and the resulting preparation was layered onto a linear Urograffin gradient (60 to 70\%). After centrifugation for 90 min at $23,000 \times g$, crystals were collected and stored at $-20^{\circ} \mathrm{C}$.

Purification of protoxins and generation of the toxic tryp- 
sin-resistant fragments were performed as described by Höfte et al. (19). Toxins were further purified as described by Hofmann et al. (18).

The protein concentrations of purified and activated deltaendotoxins were obtained by determining $A_{280}$ with a Uvikon model 810P spectrophotometer, using extinction coefficients of $73,350 \mathrm{M}^{-1} \cdot \mathrm{cm}^{-1}$ for $\operatorname{CryIA}(\mathrm{a}), 76,050$ $\mathrm{M}^{-1} \cdot \mathrm{cm}^{-1}$ for CryIA(b), $85,100 \mathrm{M}^{-1} \cdot \mathrm{cm}^{-1}$ for CryIA(c), $86,400 \mathrm{M}^{-1} \cdot \mathrm{cm}^{-1}$ for CryIB, $76,400 \mathrm{M}^{-1} \cdot \mathrm{cm}^{-1}$ for CryID, and $69,900 \mathrm{M}^{-1} \cdot \mathrm{cm}^{-1}$ for CryIE. The extinction coefficients were calculated on basis of the amino acid compositions of the different proteins.

All binding assays were performed with activated ICPs.

Toxicity assays. Toxicity assays were performed with neonate larvae of Manduca sexta and Ostrinia nubilalis. Multiwell-24 plates (Costar) were filled with an artificial diet $(2,32)$. Native and biotinylated toxins were diluted in phosphate-buffered saline (PBS) $\left(8 \mathrm{mM} \mathrm{Na} \mathrm{HPO}_{4}, 2 \mathrm{mM}\right.$ $\mathrm{KH}_{2} \mathrm{PO}_{4}, 150 \mathrm{mM} \mathrm{NaCl}$; pH 7.4) containing $0.1 \%$ bovine serum albumin (BSA). Five different concentrations were tested on 24 larvae each. Sample dilutions $(50 \mu l)$ were applied uniformly onto the food surface and allowed to dry. Two larvae were placed in each well. Levels of mortality were determined after 5 days. The toxicity data were analyzed by probit analysis (12).

Biotinylation of ICPs. Biotinyl- $N$-hydroxysuccinimide ester (catalog no. RPN28; Amersham) was used to incorporate the biotin moiety via the $\mathrm{N}$-terminal amino group and the $\varepsilon$-amino group of lysine into ICPs (1). Toxin samples were dialyzed against borate buffer $(\mathrm{pH} 8.6)(250 \mathrm{ml}$ of $0.2 \mathrm{M}$ boric acid and $87.5 \mathrm{ml}$ of $0.05 \mathrm{M}$ borax in distilled $\mathrm{H}_{2} \mathrm{O}$; final volume, 1 liter). Different molar reaction ratios of biotin molecules to ICP molecules (biotinylation ratios) were used in order to investigate the influence of the extent of biotinylation on biological activity.

After $1 \mathrm{~h}$ of incubation at room temperature, protein samples were applied to a Sephadex G-25 column to separate the biotinylated toxins from free biotin. A $1-\mu l$ portion of each of the fractions collected was spotted onto a nitrocellulose membrane. After incubation of the nitrocellulose membrane with a streptavidin-alkaline phosphatase conjugate (diluted $1 / 300$ in borate buffer [ $\mathrm{pH} 8.6]$ ), spots of biotinylated ICPs were visualized by incubation with an alkaline phosphatase substrate solution $(1.75 \mathrm{mg}$ of 5-bromo4-chloro-3-indolyl phosphate and $2.5 \mathrm{mg}$ of nitroblue tetrazolium in $10 \mathrm{ml}$ of a solution containing $100 \mathrm{mM}$ Tris, 100 $\mathrm{mM} \mathrm{NaCl}$, and $5 \mathrm{mM} \mathrm{MgCl}_{2}$ [pH 9.5]). Concentrations of the biotinylated delta-endotoxins were estimated by the method of Bradford (3), using BSA as the reference protein.

In order to ensure that the biological activity of the biotinylated ICPs was not due to the presence of a large proportion of nonbiotinylated molecules in the sample, biotinylated ICPs were purified by avidin-agarose chromatography (17). A poly-prep chromatography column (catalog no. 731-6226; Bio-Rad) was packed with monomeric avidinagarose (catalog no. A-2036; Sigma). The column was washed with 4 column volumes of PBS containing $1 \mathrm{mg}$ of $d$-biotin (catalog no. D-4501; Sigma) per ml. To displace biotin from the exchangeable binding sites, the column was washed with 10 volumes of $0.1 \mathrm{M}$ glycine- $\mathrm{HCl}(\mathrm{pH} 2)$. Subsequently, the resin was equilibrated with 3 volumes of running buffer (borate buffer [pH 8.6] containing $0.15 \mathrm{M}$ $\mathrm{NaCl}$ and $0.1 \%$ BSA). Following application of the sample, the biotinylated ICPs were eluted with running buffer containing $1 \mathrm{mg}$ of $d$-biotin per ml. Finally, biotinylated ICP samples were concentrated by ultrafiltration through a Cen- tricon 30 tube. Only the biotinylated ICP samples used in bioassays with $O$. nubilalis were purified in this way. The purity and integrity of biotinylated ICP samples were checked on a $10 \%$ sodium dodecyl sulfate-polyacrylamide gel (26) that was stained with Coomassie blue (34).

Unless otherwise specified, biotinylation of ICPs was performed at molar reaction ratios of 3.4 biotin molecules per ICP molecule.

Iodination of ICPs. CryIA(b) was iodinated by using the chloramine $\mathrm{T}$ method (22). To $50 \mu \mathrm{g}$ of purified toxin $1 \mathrm{mCi}$ of $\mathrm{Na}^{125} \mathrm{I}$ and $20 \mu \mathrm{g}$ of chloramine $\mathrm{T}$ were added. After gentle shaking for $30 \mathrm{~s}$, the reaction was stopped with $12 \mu \mathrm{l}$ of $\mathrm{K}_{2} \mathrm{~S}_{2} \mathrm{O}_{5}$. The free iodine and possible degradation products in the reaction mixture were removed by Bio-Gel P-30 (Bio-Rad Laboratories) column chromatography.

From each fraction one sample $\left(10^{5} \mathrm{cpm}\right)$ was separated on a $10 \%$ sodium dodecyl sulfate-polyacrylamide gel (26). The dried gel was exposed to Fuji XR safety film to evaluate the purity and integrity of the labeled toxins.

Isolation of brush border membrane vesicles. $M$. sexta larvae were chilled on ice for $15 \mathrm{~min}$. Head and last abdomen segments were cut off, and midguts were gently pulled out of the larvae and rinsed in ice-cold mannitol-EGTA-Tris buffer [300 mM mannitol, $5 \mathrm{mM}$ ethyleneglycol-bis( $\beta$-aminoethyl ether)- $N, N, N^{\prime}, N^{\prime}$-tetraacetic acid, $17 \mathrm{mM}$ tris(hydroxymethyl)aminomethane; $\mathrm{pH}$ 7.5). Isolated midguts were quickly frozen in liquid nitrogen.

Brush border membrane vesicles were prepared by the method of Wolfersberger et al. (39).

The protein content of the brush border membrane vesicle preparation was measured by the method of Bradford (3), using BSA as the standard.

Radioligand binding assay. Binding assays were performed under standard conditions as described by Van Rie et al. (35). M. sexta vesicles (100 $\mu \mathrm{g}$ of vesicle protein per $\mathrm{ml}$ ) were incubated with $1 \mathrm{nM}{ }^{125}$ I-labeled CryIA(b) and increasing concentrations of either unlabeled or biotinylated CryIA(b) in $100 \mu$ l (total volume) of PBS-0.1\% BSA. After 30 min of incubation, bound and free toxins were separated by ultrafiltration through Whatmann GF/F glass fiber filters. The filters were immediately washed with $5 \mathrm{ml}$ of ice-cold PBS $-0.1 \%$ BSA. The radioactivity retained on the filters was measured with a gamma counter (model 1275 Minigamma; LKB Instruments). The datum points given below correspond to the average values from duplicate tests that differed by less than $10 \%$.

Histological sections. Midgut tissue was fixed with Bouin Hollande $10 \%$ sublimate (4). Midgut tissue was incubated for $30 \mathrm{~min}$ in the fixative, transferred to fresh fixative solution for $24 \mathrm{~h}$, and subsequently washed for $12 \mathrm{~h}$ in distilled water.

The fixed tissue was dehydrated by incubation in an ethanol concentration series as follows: $70 \%$ ethanol for $1 \mathrm{~h}$; $96 \%$ ethanol for $1 \mathrm{~h} ; 1 \mathrm{~h} ; 100 \%$ ethanol for $2 \mathrm{~h}$; and $100 \%$ ethanol for $2 \mathrm{~h}$. After infiltration of $50 \%$ ethanol-50\% xylol mixture for $1 \mathrm{~h}$, a $100 \%$ xylol solution for $1 \mathrm{~h}$, and a $50 \%$ xylol-50\% Paraplast (Oxford Labware) mixture for $12 \mathrm{~h}$ at $58^{\circ} \mathrm{C}$, gut tissues were embedded in Paraplast twice for $24 \mathrm{~h}$ at $58^{\circ} \mathrm{C}$. Finally, the Paraplast was hardened with ice.

Transverse 5- $\mu \mathrm{m}$ sections were cut with an LKB historange microtome. Mounting glasses were coated with a glycerin suspension $(10 \mathrm{ml}$ of anhydrous glycerol, $1 \mathrm{~g}$ of ovalbumin, $90 \mathrm{ml}$ of distilled $\mathrm{H}_{2} \mathrm{O}, 5 \mathrm{mg}$ of thimerosal). After stretching for $10 \mathrm{~s}$ at $45^{\circ} \mathrm{C}$, tissue sections were incubated at $40^{\circ} \mathrm{C}$ for 3 days.

In vitro binding of ICPs on tissue sections. In vitro binding assays with tissue sections were performed by using isolated 
guts of untreated larvae. After deparaffination and hydration (twice with $100 \%$ xylol, three times with $100 \%$ ethanol [ $3 \mathrm{~min}$ each], and once with distilled $\mathrm{H}_{2} \mathrm{O}$ for $1 \mathrm{~min}$ ), the tissue sections were immersed twice in lugol $\left(0.5 \% \mathrm{I}_{2}\right.$ and $1 \% \mathrm{KI}$ in distilled $\mathrm{H}_{2} \mathrm{O}$ ) for $2 \mathrm{~min}$ to remove $\mathrm{HgCl}_{2}$. To bleach the preparations, the sections were incubated for $2 \mathrm{~min}$ in a $5 \%$ $\mathrm{Na}_{2} \mathrm{~S}_{2} \mathrm{O}_{5}$ solution. Finally, the sections were washed in distilled $\mathrm{H}_{2} \mathrm{O}$ for $1 \mathrm{~min}$ and immersed in Tris-saline-Triton X-100 buffer (TST buffer) (10 mM Tris, $150 \mathrm{mM} \mathrm{NaCl}, 0.1$ $\mathrm{mM}$ thimerosal, $0.1 \%$ Triton $\mathrm{X}-100$; $\mathrm{pH} \mathrm{7.6)}$ for $5 \mathrm{~min}$. Subsequently, the sections were incubated with native or biotinylated crystal proteins [10 $\mu \mathrm{g}$ of CryIA(a), CryIA(b), CryIB, CryID, or CryIE or $5 \mu \mathrm{g}$ of CryIA(c) per ml of TST buffer; $300 \mu$ l of toxin solution per mounting glass] for $30 \mathrm{~min}$ (5). To inhibit aspecific binding, tissue sections were treated with blocking solution prior to incubation with ICPs, or blocking agent was added to the ICP solution (1\% BSA or $1 \%$ lyophilized bovine milk powder in TST buffer). After 30 min of incubation, unbound ICPs were removed by washing the tissue sections with $500 \mu \mathrm{l}$ of TST buffer for $1 \mathrm{~min}$. Subsequently, the slides incubated with native ICPs were covered with an antibody solution ( $1 \mu \mathrm{g}$ of antibody per $\mathrm{ml}$ of TST buffer) for $1 \mathrm{~h}$. CryIA(a), CryIA(b), and CryIA(c) were identified with monoclonal antibody 4D6, CryIB was detected with antibody 22A2F1, CryID was detected with polyclonal antiserum ID, and CryIE was detected with 16A5E4 (21). Following removal of excess antibody with TST buffer for $1 \mathrm{~min}$, sections were incubated with peroxidase-conjugated rabbit anti-mouse or goat anti-rabbit antibody for $1 \mathrm{~h}$ ( $5 \mu \mathrm{g}$ of antibody per ml of TST buffer). Finally, unbound secondary antibody was washed off with TST buffer for $1 \mathrm{~min}$, and sections were transferred to a $50 \mathrm{mM}$ Tris stock solution ( $\mathrm{pH} 7.6$ ) containing peroxidase substrate (0.01\% 3,3'-diaminobenzidine plus $0.0035 \% \mathrm{H}_{2} \mathrm{O}_{2}$ in Tris stock).

Slides incubated with the biotinylated ICPs were covered with a streptavidin-peroxidase or streptavidin-alkaline phosphatase conjugate. Following removal of free streptavidinenzyme conjugate with $500 \mu$ l of TST buffer, tissue sections were transferred to a substrate solution (alkaline phosphatase substrate consisting of $1.75 \mathrm{mg}$ of 5-bromo-4-chloro3-indolyl phosphate plus $2.5 \mathrm{mg}$ of nitroblue tetrazolium in $10 \mathrm{ml}$ of a solution containing $100 \mathrm{mM}$ Tris, $100 \mathrm{mM} \mathrm{NaCl}$, and $5 \mathrm{mM} \mathrm{MgCl}_{2}$ [pH 9.5]).

To preserve stained tissues, the sections were dried on a heating plate and covered with Entellan mounting medium (Merck).

ICPs, primary antibodies, enzyme-conjugated secondary antibodies, biotinylated ICPs, and enzyme-conjugated streptavidin were sequentially omitted to exclude falsepositive results from the tissue binding analysis.

\section{RESULTS}

Toxicity of biotinylated $B$. thuringiensis ICPs. For the analysis of toxicity of biotinylated CryIA(b) to $M$. sexta, molar reaction ratios of $0.85,3.4$, and 8.5 biotin molecules per ICP molecule were used. Toxicity assays with $O$. nubilalis were performed with CryIA(b) labeled at molar reaction ratios of $3.4,17$, and 34 biotin molecules per CryIA(b) molecule. For $M$. sexta $50 \%$ lethal concentrations were calculated, and likelihood ratio tests for equality and parallelism were performed (12). From these calculations it was concluded that molar reaction ratios of up to 8.5 biotin molecules per CryIA(b) molecule did not interfere with toxicity of CrylA(b) to $M$. sexta larvae (Table 1 ). Also, with
TABLE 1. Toxicity of native and biotinylated CryIA(b) to $L_{1}$ larvae of $M$. sexta ${ }^{a}$

\begin{tabular}{|c|c|}
\hline $\begin{array}{l}\text { Biotinylation ratio [no. of biotin } \\
\text { molecules per CryIA(b) molecule] }\end{array}$ & $\begin{array}{c}50 \% \text { Lethal } \\
\text { concn }\left(\mathrm{ng} / \mathrm{cm}^{2}\right)\end{array}$ \\
\hline 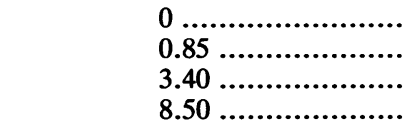 & $\begin{array}{l}.10 .8(6.6-17.4) \\
.12 .0(7.5-19.3) \\
.10 .3(7.0-15.0) \\
.13 .0(8.6-19.9)\end{array}$ \\
\hline
\end{tabular}

a $50 \%$ Lethal concentrations and $95 \%$ confidence limits (values in parentheses) were calculated from probit analysis. Doses are expressed in nanograms of toxin applied per cm square centimeter of artificial medium.

O. nubilalis, biotinylation of CryIA(b) in which biotinylation ratios of up to 17 biotin molecules per CryIA(b) molecule were used did not result in any decrease in toxic activity. Only when very high ratios of biotin to ICP were used (34 biotin molecules per ICP molecule) was a significant reduction in biological activity observed. The levels of toxicity of native and biotinylated CryIA(b) to $\mathrm{L}_{1}$ larvae of $O$. nubilalis [expressed as percentages of the toxicity of native CryIA(b)] were $100,100,100$, and $39 \%$ for preparations containing 0 , $3.4,17$, and 34 biotin molecules per CryIA(b) molecule, respectively.

The toxic effects of biotinylated CryIA(b) were also evaluated by force feeding the biotin-labeled ICP to $O$. nubilalis larvae. After fixation of the midgut tissue, histological sections were prepared, and the tissue was stained by the Heidenhain's Azan method (7). Histological effects such as hypertrophy and vacuolation of epithelial cells and disruption of the microvillar brush border were identical to the effects observed with native CryIA(b) (Fig. 1).

Competitive radioreceptor assay of biotinylated CrylA(b). A homologous competition experiment was performed to compare the capacities of native CryIA(b) and biotinylated CryIA(b) (biotinylation ratio, 3.4) to compete with ${ }^{125} \mathrm{I}$ labeled CryIA(b) for binding to brush border membrane vesicles of $M$. sexta. A nonlinear regression analysis $(15,31)$ showed that the displacement curves for native and biotinylated CryIA(b) were very similar (Fig. 2). The curve for biotinylated CryIA(b) exhibited only a slight shift to the right, indicating that there was a minor reduction in binding affinity.

In vitro binding of biotinylated ICPs on tissue sections. Binding experiments with biotinylated ICPs were performed with tissue sections of $M$. sexta, $O$. nubilalis, and Plutella xylostella. Initially, detection of the binding of biotinylated ICPs to midgut tissue sections by using a streptavidinenzyme conjugate was compared with antibody detection of the binding of native ICPs. Therefore, midgut tissue sections of $O$. nubilalis were incubated with CryIA(b) biotinylated at molar reaction ratios of $3.4,17$, and 34 . The staining intensities of the brush border membrane after reaction of streptavidin-conjugated enzymes with the appropriate substrates were very similar for the differentially biotinylated CryIA(b) samples. From this experiment we concluded that a biotinylation ratio of 3.4 should be used for routine labeling of ICPs. Furthermore, the binding pattern along the midgut epithelia of $O$. nubilalis, $M$. sexta, and $P$. xylostella and the staining intensity of biotinylated ICPs detected with streptavidinenzyme conjugate were virtually identical to the binding pattern and staining intensity of native CryIA(b) detected with antibodies.

To investigate the specificity of the binding of biotinylated ICPs to midgut tissue sections, homologous competition 


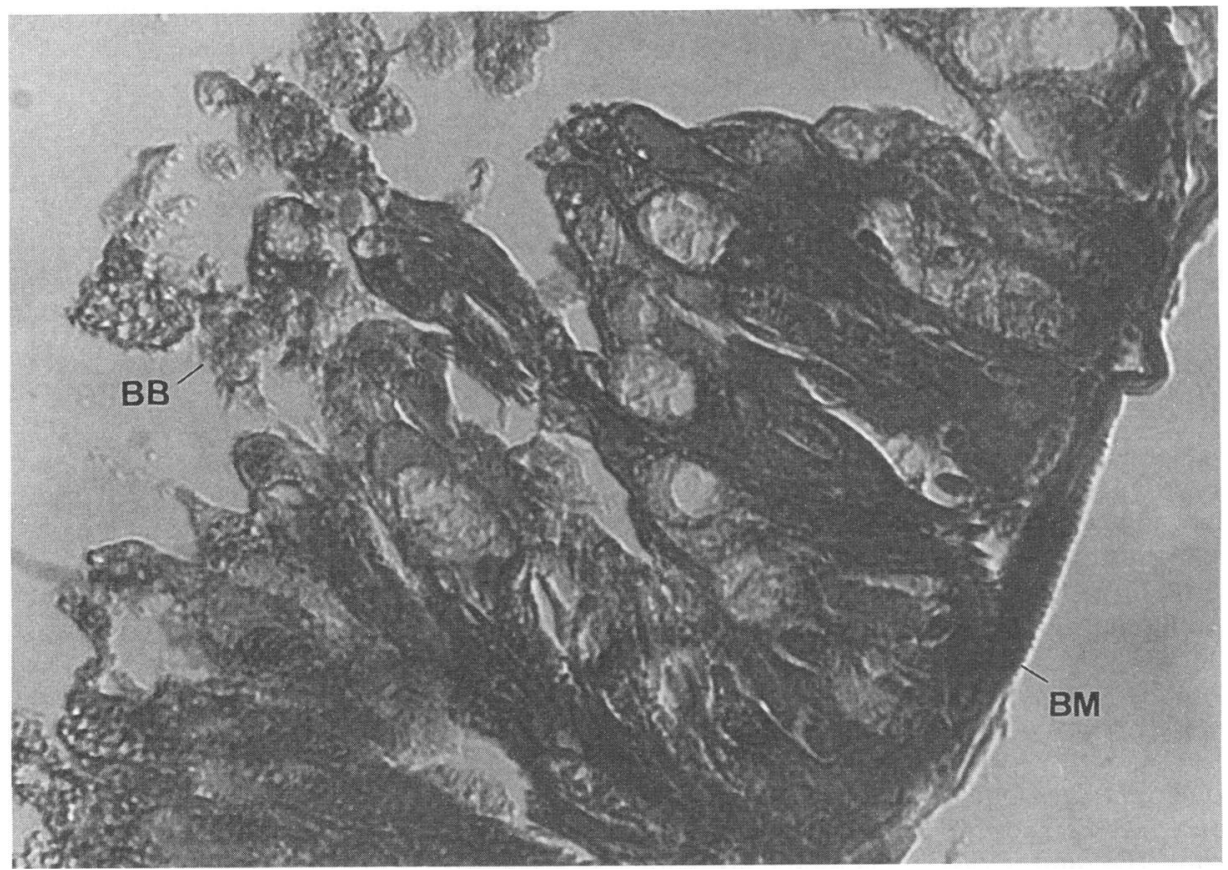

FIG. 1. Heidenhain's Azan-stained midgut epithelium of an $\mathrm{L}_{5}$ larva of $O$. nubilalis dissected $1 \mathrm{~h}$ after treatment with biotinylated CryIA(b) ICP (biotinylation ratio, 3.4). The histopathological effects are the same as those observed after treatment with native CryIA(b) (namely, hypertrophy and vacuolation of epithelial cells and disruption of the microvillar brush border). BB, brush border membrane; BM, basement membrane. Light micrograph obtained with Nomarski differential interference contrast illumination. Magnification, $\times 500$.

experiments (competition between a labeled ICP and its native analog) were performed. Binding of biotinylated CryIA(b) was analyzed in the presence of a 100 -fold excess of native CryIA(b). For $M$. sexta (Fig. 3), as well as for $O$. nubilalis (9) and $P$. xylostella, the presence of excess unlabeled ICP resulted in a complete disappearance of brush border membrane staining. Similar results were obtained for the homologous competition experiments performed with CryIA(a), CryIA(c), and CryIB and midgut tissue sections of

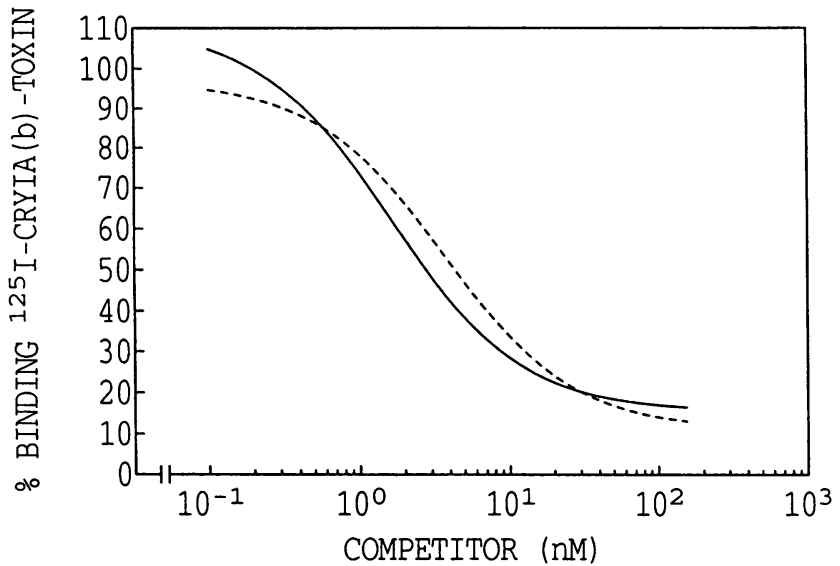

FIG. 2. Binding of ${ }^{125} \mathrm{I}$-labeled CryIA(b) to brush border membrane vesicles of $M$. sexta. Vesicles were incubated for $30 \mathrm{~min}$ with ${ }^{125} \mathrm{I}$-labeled CryIA(b) in the presence of increasing concentrations of native ( - ) or biotinylated (-- ) CryIA(b). Binding is expressed as a percentage of the amount bound upon incubation with the ${ }^{125} \mathrm{I}$ labeled toxin alone. Nonspecific binding values were not subtracted.
P. xylostella (data not shown). Binding of biotinylated CryID and CryIE was also investigated. These ICPs are not toxic to $O$. nubilalis (9) and $P$. xylostella (11) and could not be detected after incubation on midgut tissue sections from these insects (data not shown).

In order to investigate the usefulness of biotinylated ICPs for analyzing the relationship between different ICP receptors, heterologous competition experiments (competition between a labeled ICP and another, unlabeled ICP) were performed with sections of $P$. xylostella (Fig. 4). Radioligand binding experiments have demonstrated that this insect possesses at least three different ICP receptors [receptors for CryIA(b), CryIB, and CryIC] (11). Incubation of $P$. xylostella sections with biotinylated CryIB in the presence of a 100 -fold excess of CrylA(b) resulted in a staining intensity that was identical to the staining intensity obtained after incubation with biotinylated CryIB alone. The inverse experiment, in which biotinylated CryIA(b) and an excess of native CryIB were used, yielded similar results.

\section{DISCUSSION}

The aim of our study was to evaluate the usefulness of $B$. thuringiensis ICP biotinylation in order to establish an alternative method for the screening for novel, interesting ICPs toxic to pest insects and for ICP receptor characterization.

To investigate whether biotinylated ICPs retained their biological activity, toxicity assays were performed, histological effects were studied, and a competitive radioreceptor assay was performed. The use of molar reaction ratios of up to 8.5 and 17 biotin molecules per ICP molecule did not reduce the toxicity of CryIA(b) to $M$. sexta and $O$. nubilalis, respectively. Only when very high biotinylation ratios were 


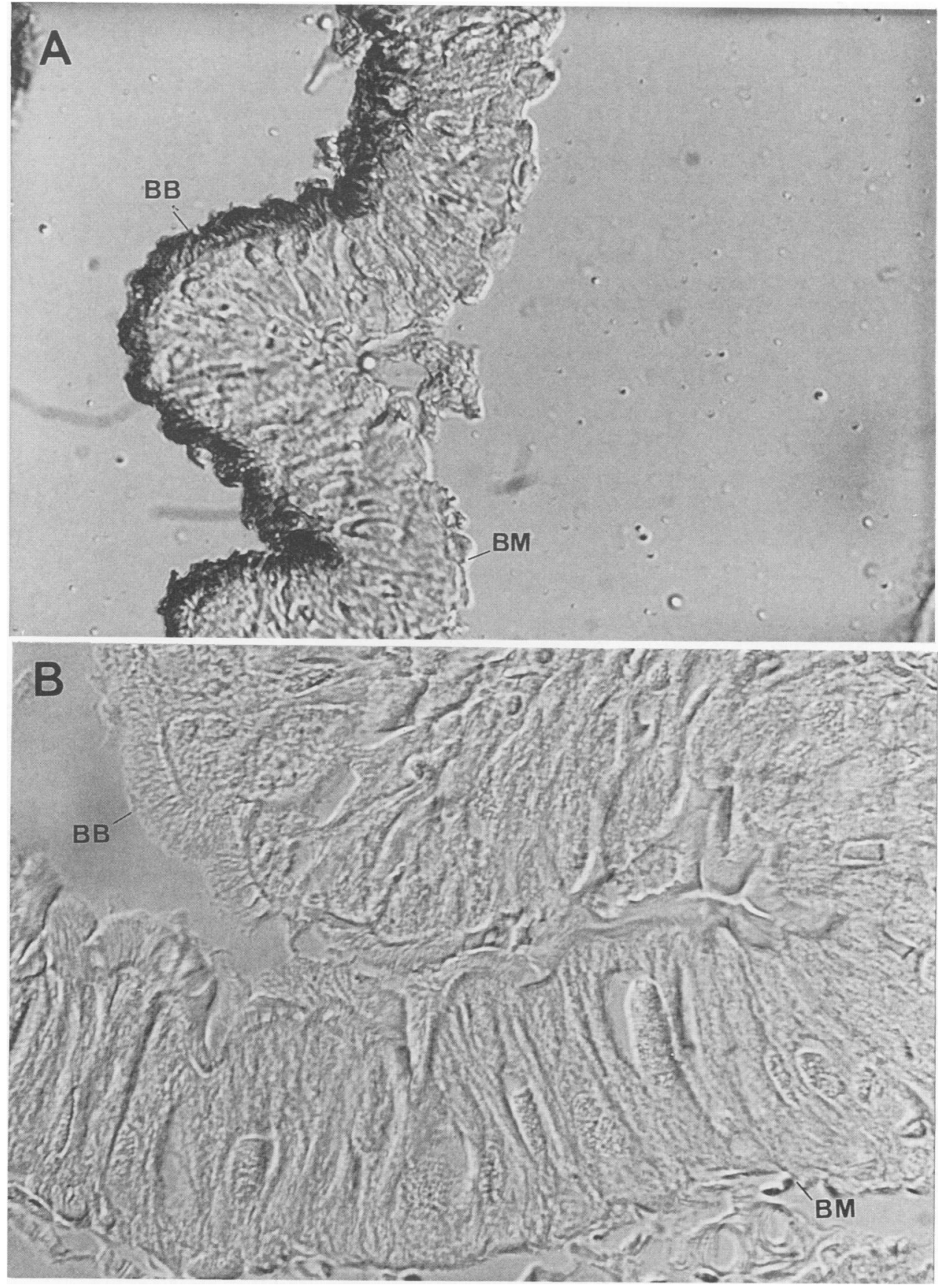

FIG. 3. (A) Binding of biotinylated CryIA(b) to the brush border membrane of $M$. sexta. Biotinylated CryIA(b) binds to the microvillar brush border throughout the midgut. (B) When tissue sections were incubated with biotinylated CryIA(b) in the presence of a 100-fold excess of unlabeled CryIA(b), no biotinylated CryIA(b) binding was detected. BB, brush border membrane; BM, basement membrane. Light micrographs obtained with Nomarski differential interference contrast illumination. (A) Magnification, $\times 125$. (B) Magnification, $\times 250$.

used did biotinylation interfere with ICP toxicity. Furthermore, the histological effects induced by force feeding with biotinylated CryIA(b) were the same as the effects observed following force feeding with native CryIA(b). Finally, biotinylated CryIA(b) retained the capacity of native ICP to displace ${ }^{125}$ I-labeled CryIA(b) completely from its binding site on brush border membrane vesicles of $M$. sexta. Only a minor reduction in the binding affinity of the biotin-labeled
ICP was observed. Taken together, these data indicate that biotinylation does not significantly interfere with the biological activity of ICPs, as long as the biotinylation ratios do not exceed certain limits.

In a comparison with antibody detection of ICP binding on midgut tissue sections, detection of biotinylated ICPs by using a streptavidin-enzyme conjugate resulted in similar binding patterns and staining intensities along the epithelial 


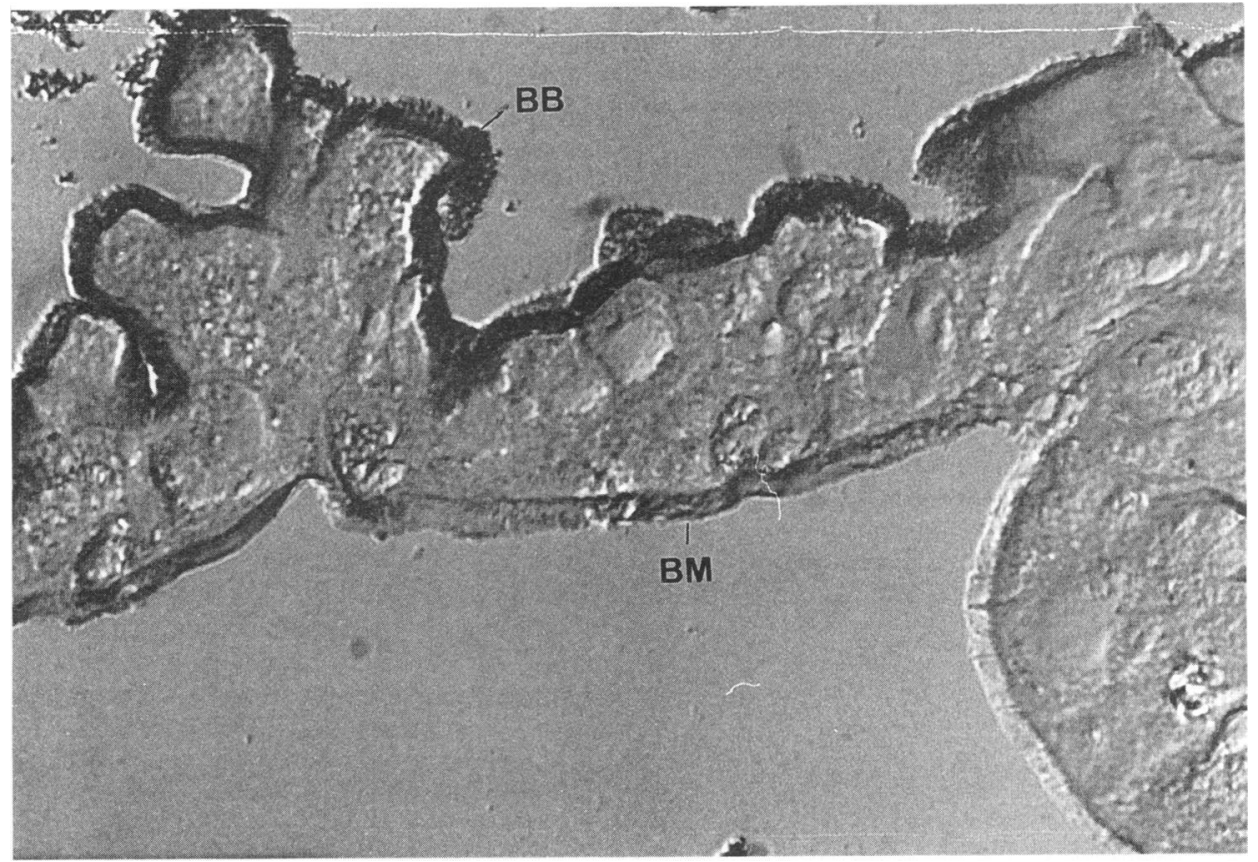

FIG. 4. Binding of biotinylated CryIB to the brush border membrane of $P$. xylostella. After incubation of the tissue section with biotinylated CryIB in the presence of a 100 -fold excess of unlabeled CryIA(b), biotinylated CryIB still bound to the midgut brush border membrane. BB, brush border membrane; BM, basement membrane. Increased shading of the basement membrane occurred because of uneven illumination across the micrograph. Light micrograph obtained with Nomarski differential interference contrast illumination. Magnification, $\times 500$.

microvilli of the midguts of lepidopteran insect species such as $M$. sexta, $O$. nubilalis, and $P$. xylostella. Moreover, the observation that an excess of unlabeled CryIA(b) completely inhibited binding of biotinylated CryIA(b) demonstrated that the observed staining resulted from a specific binding phenomenon and not from nonspecific adherence. Similar conclusions were made after incubation of $P$. xylostella sections with CryIA(a), CryIA(c), and CryIB. Binding of biotinylated CryID and CryIE, two ICPs that are not toxic to $P$. xylostella, could not be detected. A similar correlation between toxicity and binding on tissue sections has been observed for O. nubilalis (9). These observations indicate that it may be possible to predict the toxic activity of ICPs from their binding behavior on tissue sections. Indeed, since binding of ICPs to the brush border membranes of larvae is usually correlated with toxicity of ICPs, biotinylated ICPs, in combination with larval tissue sections, offer an attractive alternative screening method for identifying ICPs with activity against a target pest. In contrast to current screening activities which require the constant rearing of different insect populations to perform bioassays $(18,35)$, screening based on tissue section binding experiments can be performed with very few larval guts (5). The initial need for antibodies to detect bound ICPs and the inherent limitation of the tissue binding assay to those ICPs against which antibodies are available have been overcome by ICP biotinylation. Screening for novel ICPs through binding experiments with biotinylated ICPs on midgut sections could be especially useful for insect species that present problems in bioassays because of their small size or difficult rearing conditions. On the other hand, the results of binding experiments with biotinylated ICPs must be confirmed by bioassays since the correlation between ICP binding and ICP toxicity does not always hold (13).

ICP biotinylation allows workers to investigate the relationships between different ICP receptors by using tissue sections. The presence of different receptors for CryIA(b) and CryIB in P. xylostella (this study) and $O$. nubilalis (9), as inferred from the results of radioligand competition experiments, was confirmed by results from heterologous competition experiments performed with biotinylated and native ICPs. Thus, in addition to its possible use as a screening methodol, biotinylation of ICPs offers a simple alternative to radioligand competition binding assays for investigating the relationships between receptor sites. In this way, this technology should permit selection of useful, independently acting ICPs which can be used in combination or rotation application programs $(14,16,29)$ in order to reduce the chance of development of resistance.

\section{ACKNOWLEDGMENTS}

We thank Bernadette Saey and Linda Buysse for insect rearing and toxicity assays.

P.D. was supported by a grant from the Instituut tot Aanmoediging van Wetenschappelijk Onderzoek in Nijverheid en Landbouw and by the Algemene Spaar- en Lijfrentekas. This work was supported in part by a grant from the European Community under the ISC program.

\section{REFERENCES}

1. Bayer, E., and M. Wilcheck. 1990. Protein biotinylation. Methods Enzymol. 184:138-159.

2. Bell, R., and F. Joachim. 1976. Techniques for rearing laboratory colonies of tobacco hornworms and pink bollworms. Ann. 
Entomol. Soc. Am. 69:365-373.

3. Bradford, M. M. 1976. A rapid and sensitive method for the quantitation of microgram quantities of protein utilizing the principle of protein-dye binding. Anal. Biochem. 72:248-254.

4. Brandtzaeg, P. 1982. Tissue preparation methods for immunocytochemistry, p. 49-51. In G. Bullock and P. Petrusz (ed.), Techniques in immunocytochemistry. Academic Press, London.

5. Bravo, A., K. Hendrickx, S. Jansens, and M. Peferoen. 1992. Immunocytochemical analysis of specific binding of Bacillus thuringiensis insecticidal crystal proteins to lepidopteran and coleopteran midgut membranes. J. Invertebr. Pathol. 60:247253.

6. Brizzard, B., and H. Whiteley. 1988. Nucleotide sequence of an additional crystal protein gene cloned from Bacillus thuringiensis subsp. thuringiensis. Nucleic Acids Res. 16:4168-4169.

7. Clarck, G. 1981. Heidenhain's Azan modification staining method, p. 117-118. In G. Clarck (ed.), Staining procedures. Williams and Wilkins, London.

8. Delello, E., W. Hanton, S. Bishoff, and D. Mish. 1984. Histopathological effects of Bacillus thuringiensis on the midgut of tobacco hornworm larvae (Manduca sexta): low doses compared with fasting. J. Invertebr. Pathol. 43:169-181.

9. Denolf, P., S. Jansens, M. Peferoen, D. Degheele, and J. Van Rie. 1993. Two different Bacillus thuringiensis delta-endotoxin receptors in the brush border membrane of the European corn borer, Ostrinia nubilalis (Hübner) (Lepidoptera: Pyralidae). Appl. Environ. Microbiol. 59:1828-1837.

10. Ellar, D., W. Thomas, B. Knowles, S. Ward, J. Todd, F. Drobniewski, J. Lewis, T. Sawyer, D. Last, and C. Nichols. 1985. Biochemistry, genetics and mode of action of Bacillus thuringiensis delta-endotoxins, p. 230-240. In J. Hoch and P. Setlow (ed.), Molecular biology of microbial differentiation. American Society for Microbiology, Washington, D.C.

11. Ferre, J., M. Real, J. Van Rie, S. Jansens, and M. Peferoen. 1991. Resistance to the Bacillus thuringiensis bioinsecticide in a field population of Plutella xylostella is due to a change in a midgut membrane receptor. Proc. Natl. Acad. Sci. USA 88: 5119-5123.

12. Finney, D. 1962. Probit analysis. Cambridge University Press, Cambridge.

13. Garczynski, S., J. Crim, and M. Adang. 1991. Identification of putative insect brush border membrane-binding molecules specific to Bacillus thuringiensis delta-endotoxin by protein blot analysis. Appl. Environ. Microbiol. 57:2816-2820.

14. Georghiou, G. 1990. Resistance potential to biopesticides and consideration of countermeasures, p. 409-420. In J. Casida (ed.), Pesticides and alternatives. Elsevier Science Publishers BV, Amsterdam.

15. Gomez, K., and A. Gomez. 1983. Statistical procedures for agricultural research. John Wiley \& Sons, Inc., New York.

16. Gould, F. 1988. Evolutionary biology and genetically engineered crops. Consideration of evolutionary theory can aid in crop design. BioScience 38:26-33.

17. Henrikson, K., G. Allen, and L. Maloy. 1979. An avidin monomer affinity column for the purification of biotin-containing enzymes. Anal. Biochem. 94:366-370.

18. Hofmann, C., H. Vanderbruggen, H. Hofte, J. Van Rie, S. Jansens, and H. Van Mellaert. 1988. Specificity of Bacillus thuringiensis delta-endotoxins is correlated with the presence of high-affinity binding sites in the brush border membrane of target insect midguts. Proc. Natl. Acad. Sci. USA 85:7844 7848.

19. Höfte, H., H. De Greve, J. Seurinck, S. Jansens, J. Mahillon, C. Ampe, J. Vandekerckhove, H. Vanderbruggen, M. Van Montagu, M. Zabeau, and M. Vaeck. 1986. Structural and functional analysis of a cloned delta-endotoxin of Bacillus thuringiensis Berliner 1715. Eur. J. Biochem. 161:273-280.

20. Höfte, H., P. Soetaert, S. Jansens, and M. Peferoen. 1990. Nucleotide sequence and deduced amino acid sequence of a new Lepidoptera-specific crystal protein gene from Bacillus thuringiensis. Nucleic Acids Res. 18:5545.
21. Höfte, H., J. Van Rie, S. Jansens, A. Van Houtven, H. Vanderbruggen, and M. Vaeck. 1988. Monoclonal antibody analysis and insecticidal spectrum of three types of lepidopteran-specific insecticidal crystal proteins of Bacillus thuringiensis. Appl. Environ. Microbiol. 54:2010-2017.

22. Hunter, W., and F. Greenwood. 1962. Preparation of iodine-131 labelled human growth hormone of high specific activity. Science 194:495-496.

23. Knowles, B., and D. Ellar. 1987. Colloid-osmotic lysis is a general feature of the mechanism of action of Bacillus thuringiensis delta-endotoxins with different insect specificities. Biochim. Biophys. Acta 924:509-518.

24. Krieg, A., A. Huger, G. Langenbruch, and W. Schnetter. 1983. Bacillus thuringiensis var. tenebrionis: ein neuer gegenuber larven von coleopteren wirksamer pathotyp. Z. Angew. Entomol. 96:500-508.

25. Kronstad, J., and H. Whiteley. 1986. Three classes of homologous Bacillus thuringiensis crystal protein genes. Gene 43:2940.

26. Laemmli, U. K. 1970. Cleavage of structural proteins during the assembly of the head of bacteriophage T4. Nature (London) 227:680-685.

27. Macintosh, S., T. Stone, S. Sims, P. Hunst, J. Greenplate, P. Marrone, F. Perlak, D. Fischhoff, and R. Fuchs. 1990. Specificity and efficacy of purified Bacillus thuringiensis proteins against agronomically important insects. J. Invertebr. Pathol. 56:258 266.

28. Mahillon, J., and J. Delcour. 1984. A convenient procedure for the preparation of highly purified parasporal crystals of Bacillus thuringiensis. J. Microbiol. Methods 3:69-76.

29. Mani, G. 1985. Evolution of resistance in the presence of two insecticides. Genetics 109:761-783.

30. Mathavan, S., P. Sudha, and S. Pechimutu. 1989. Effect of Bacillus thuringiensis on the midgut cells of Bombyx mori larvae: a histopathological and histochemical study. J. Invertebr. Pathol. 53:217-227.

31. Motulski, H., M. Di Maggio, and R. Lowe. 1987. GraphPAD. Plot, analyze data and digitize graphs. ISI Software, Philadelphia.

32. Poitout, S., R. Bues, and C. Le Rumeur. 1972. Elevage sur milieu artificiel simple de deux noctuelles parasites du cotton Earias insulana et Spodoptera littoralis. Entomol. Exp. Appl. 15:341-350.

33. Sacchi, V., P. Parenti, G. Hanozet, B. Giordana, P. Luthy, and M. Wolfersberger. 1986. Bacillus thuringiensis toxin inhibits $\mathrm{K}^{+}$-gradient-dependent amino acid transport across the brush border membrane of Pieris brassicae midgut cells. FEBS Lett. 204:213-218

34. Sambrook, J., E. F. Fritsch, and T. Maniatis. 1989. Molecular cloning: a laboratory manual. Cold Spring Harbor Laboratory Press, Cold Spring Harbor, N.Y.

35. Van Rie, J., S. Jansens, H. Höfte, D. Degheele, and H. Van Mellaert. 1989. Specificity of Bacillus thuringiensis delta-endotoxins. Importance of specific receptors on the brush border membrane of the midgut of target insects. Eur. J. Biochem. 186:239-247.

36. Van Rie, J., S. Jansens, H. Höfte, D. Degheele, and H. Van Mellaert. 1990. Receptors on the brush border membrane of the insect midgut as determinants of the specificity of Bacillus thuringiensis delta-endotoxins. Appl. Environ. Microbiol. 56: 1378-1385.

37. Van Rie, J., W. McGaughey, D. Johnson, B. Barnett, and H. Van Mellaert. 1990. Mechanism of resistance to the microbial insecticide Bacillus thuringiensis. Science 247:72-74.

38. Visser, B., E. Munsterman, A. Stoker, and W. Dirkse. 1990. A novel Bacillus thuringiensis gene encoding a Spodoptera exigua-specific crystal protein. J. Bacteriol. 172:6783-6788.

39. Wolfersberger, M., P. Luthy, A. Maurer, P. Parenti, V. Sacchi, B. Giordana, and G. Hanozet. 1987. Preparation and partial characterization of amino acid transporting brush border membrane vesicles from the larval midgut of the cabbage butterfly (Pieris brassicae). Comp. Biochem. Physiol. 86:301-308. 